\title{
POETRY
}

\section{The marathon runner}

Most nights, there is a familiar routine:

The chirping pagers,

The bustling emergency department, The bolus of admissions,

The janitorial staff sleepily polishing everything,

The dimming of lights on the wards,

The soft Soul tunes from the

secretary's desk,

The three o'clock lull,

The quiet hallways,

The disquieting cafeteria options,

The families calling for updates,

The battle against sun-downing that lasts until sun-up.

But for you, this night was not the same,

Nor will any night ever be again.

You were my last admission that night

(Or was it morning?)

Young, in fact, my age,

With a lung mass the size of a softball,

And all the classic symptoms

They teach about lymphoma in the textbooks.

Anxious, trembling; your fear

Amplified by the vitality of your youth.

A marathon runner not three months ago,

And a life unbridled and free not two hours ago.

At this hour, without specialty backup,

I did what I could.

Sitting there, quietly, offering you tissues,

Both of us feeling crushed by mortality,

Heavy in the air.

\section{Ryan Childers MD}

Division of Gastroenterology

Department of Medicine

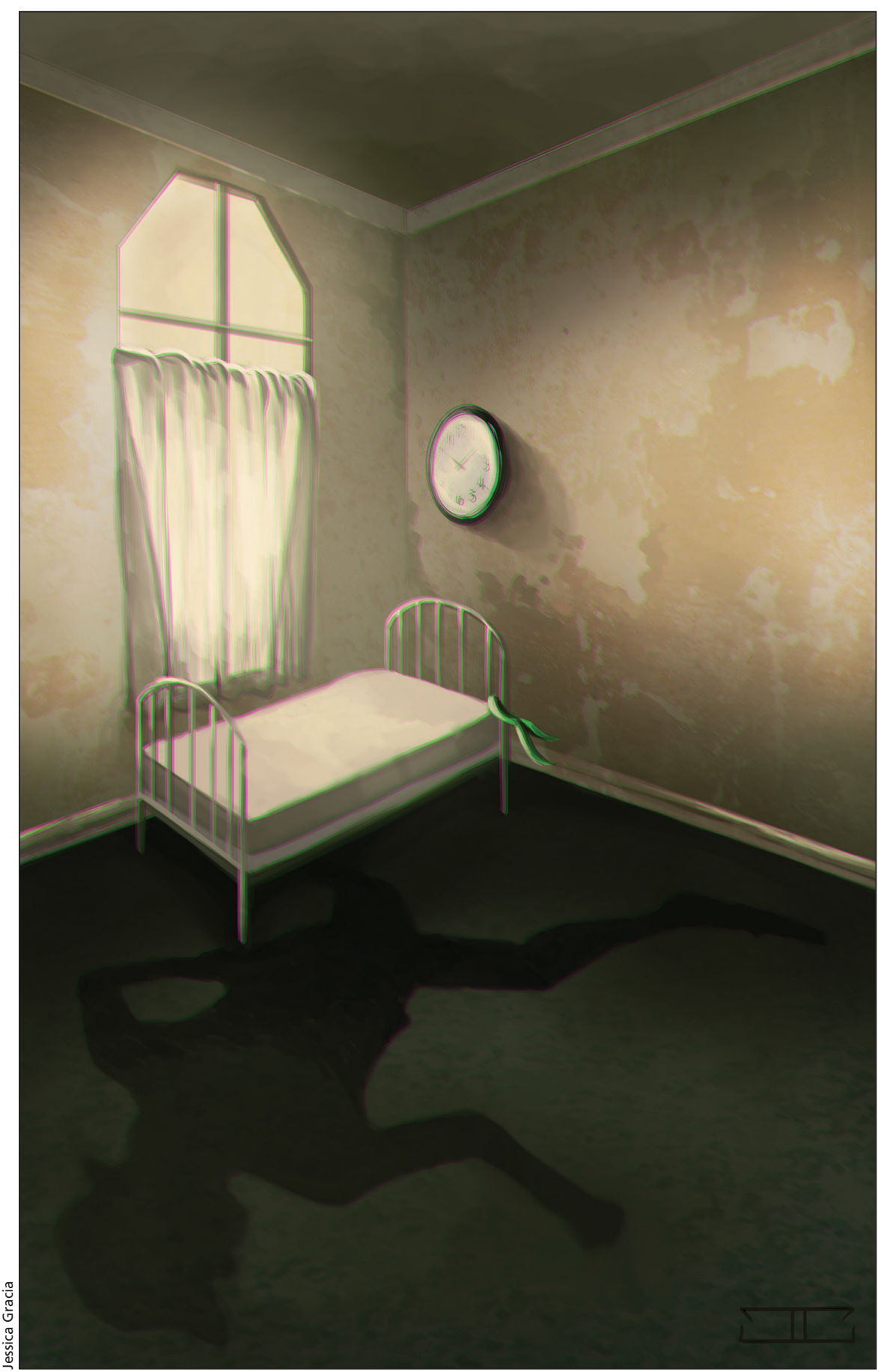

Oregon Health and Science University Portland, Ore.

CMAJ 2015. DOI:10.1503/cmaj.140765 